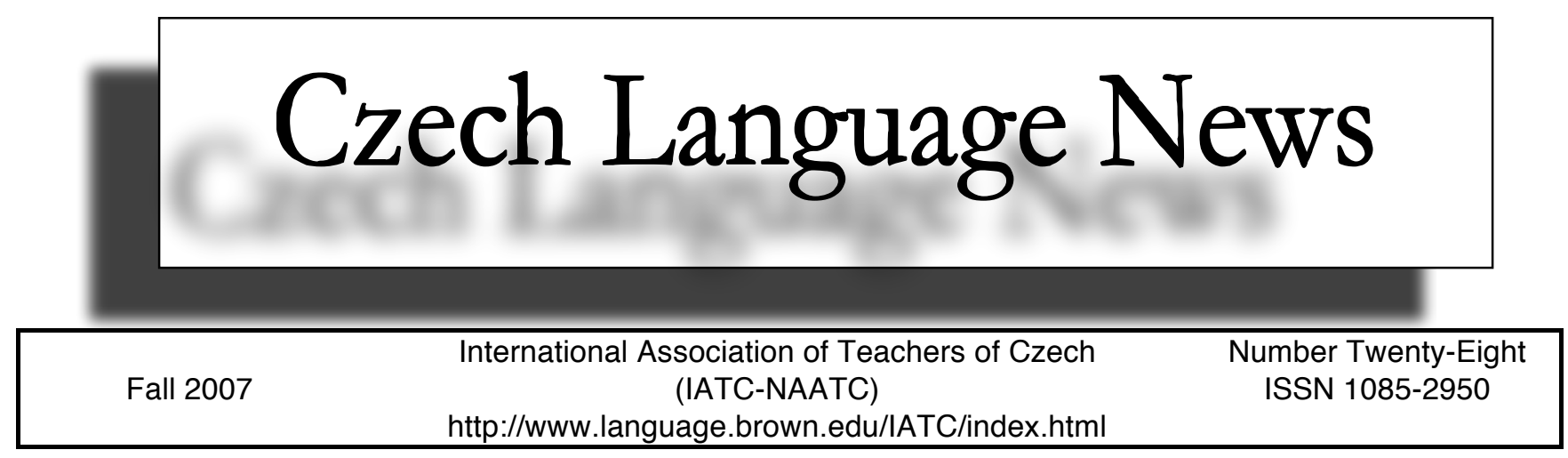

\title{
Message from the Presidents
}

This issue of Czech Language News highlights the Czech educational system, with articles by Professor Milan Malinovský on post-1989 reforms in the Czech system of education, and by Professors Radim Palouš and Aleš Prázný on the pedagogical foundations of the philosophy of Jan Patočka. As these articles demonstrate, we are working on broadening the authorship base of Czech language News, and we welcome contributions from all colleagues on topics relating to the Czech language, Czech culture, Czech heritage, and methodology. In addition, we always welcome reviews for publication, so please keep us in mind when you come into contact with useful resources relating to Czech, either in print or on the Internet.

We would also like to invite you to our annual meeting at the AATSEEL conference, held this year in Chicago, Saturday, December 29th at 7pm. After the meeting Dr. Jeffrey Holdeman of Indiana University will host an Evening of Czech Music.

The next meeting of our sister organization, Asociace učitelů češtiny jako cizího jazyka, will be held on December 1, 2007 and will focus on film, the Internet, and the use of authentic materials for teaching Czech.

We wish you a successful and inspiring 2007-08 academic year.

Sincerely,

Dr. Craig Cravens, University of Texas, Austin, svejk@mail.utexas.edu

Dr. Susan Kresin, University of California, Los Angeles, kresin@humanities.ucla.edu

\section{Contents}

The Educational System of the Czech Republic and Foreign Language Learning by Milan Malinovský...........2

The Pedagogical Foundations of the Philosophy of Jan Patočka by Radim Palouš and Aleš Prázný................7

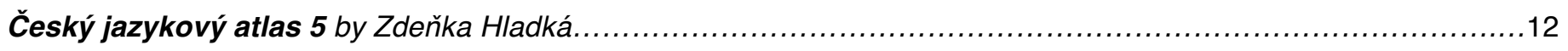

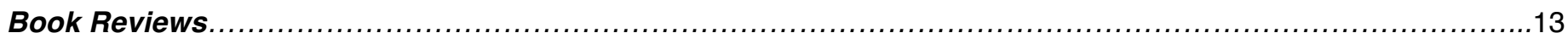

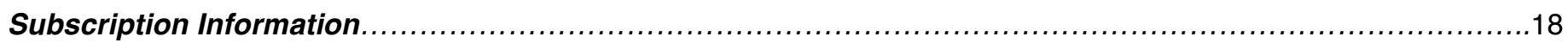




\section{The Educational System of the Czech Republic and Foreign Language Learning}

\author{
M. Malinovský \\ Czech Technical University \\ College of Civil Engineering, Prague
}

The Czech educational system has been undergoing an extensive transformation for the past eighteen years, and is gradually overcoming the problems created during the preceding decades. In the study of foreign languages, fundamental changes occurred in institutionalized education after 1989. The politically and ideologically motivated predominance of Russian language study ended and was replaced by the language policy of the Council of Europe, of which the Czech Republic became a member in 1990.

$1 \quad$ In the first rush of "revolutionary" changes in 1990 , some of the most egregious aspects of the communist educational system were repaired: e.g. the ideological background of the educational program. Not surprisingly, new mistakes also occurred, too, such as an uncontrolled growth in the number of new schools, which, combined with the rapid drop of birthrate, subsequently led to serious problems.

Nonetheless, a number of successful accomplishments can be noted:

- the establishment of private and other non-state schools ; their overall weight in the educational system is not significant (below $10 \%$ of students), but they serve as useful competition to the traditional establishments

- decentralization of the school system; enhancement of school autonomy

- normative financing of schools on a perchild/per-student basis

- rapid improvement of foreign language teaching

- thorough replacement of obsolete schoolbooks by the opening of a free market and competition

- establishment of a dozen new regional universities

- rapid growth in the number of students in higher education

- re-introduction of academic freedoms and institutional self-government

- establishment of a State Grant Agency to support research activities

In the following years, substantial reforms of curricula were conducted, vocational training improved, discrimination of handicapped children alleviated, and universities transformed to public non-profit legal subjects with full freedom of instruction and management.

The main problems persisting include:

- the problem of educating socially marginalized children, especially in Roma communities

- the need to affirm the comparability of highschool diploma across schools by reintroducing obligatory and (partly) unified/standardized "maturita/maturitní zkouška"

(= secondary school-exit examination)

- a thorough lack of reform of university education along the lines of the Bologna Declaration

- an enduring deficiency in cooperation between the Academy of Sciences and the universities

- a lack of new investments in higher education, especially libraries

- weak support for life-long learning

At present, there is extensive public debate in the Czech Republic about the possible introduction of partial-tuition fees for higher education, which, to this day, is fully funded by the state and free to students. Though the number of admissions rises continuously (in fact, it has doubled since 1990), a third of college applicants still fails to find placement. By a decision of Parliament, the educational system has been even more decentralized since 2001, creating in turn new problems regarding the comparability of educational results throughout the country. The government also started a large program of computerization in schools, including Internet connection in all schools.

\section{Structure of the Czech educational system} Pre-higher, or basic compulsory education is provided by Primary, or Elementary, Schools in two stages: 1-5, 6-9. The length of the program is nine years, and the age levels six to fifteen. The certificate/diploma awarded is "vysvědčení."

\subsection{Secondary education}

Primary schools approve the educational results of students indicated in an application. Students sit for (written or oral) entrance examinations at the secondary schools where they send their applications; they may apply for admittance to one or more schools, depending on their preference. Prior to applying, students and parents alike can consult regarding their decisions with teachers, with academic advisers employed within the schools, or in academic-psychological consulting centres.

The content of examinations is determined by the individual school on the basis of the primary school curriculum and with regard to its own educational profile. The criteria which are influence admissions are as follows: 
- the results of secondary school entrance examinations (usually taken in Czech language and mathematics, sometimes in a foreign language; or, in art and sports schools, in subjects relating to the school's focus and students' individual talents),

- primary school certificate, and

- sometimes, the results of psychological tests.

The decision on the number of accepted applicants as well as the specific applicants that are accepted is within the competency of the secondary school principal. An appeal against his/her decision may be submitted to the director of the respective department of the District Office who executes the powers entrusted to him/her by the state administration in the field of education. Regulations permit a student to change his or her study program in an apprentice training school or vocational school, or to move to a different type of secondary school. In any case, however, the decision on admissions is in the competency of the school headmaster and the student must sit in for an entrance examination in almost every case.

Secondary schools are divided into:

- secondary general/grammar schools

- secondary vocational schools

- secondary apprentice training centres

- higher vocational schools

Secondary education is a structured but internally coordinated system providing education and practical vocational training for almost the entire population of young people once their compulsory education has been completed and prior to the start of their starting a job or entering a university. Secondary schools are attended by students aged fifteen to nineteen years. The initial age limit depends on the year in which students finish their compulsory education at the primary school. There are two tasks within secondary schools; either to prepare students for their future occupations and for their activities in the national economy, administration, culture, arts, and other spheres of human life; or to prepare them for further education at a higher level.

The secondary studies culminate in the passing of "maturitní zkouska" ("school-exit examination"), colloquially called "maturita," which is required for graduation from secondary studies.

Developments in secondary education represent one of the most significant changes carried out in the Czech educational system after 1989. The proportion of students admitted to study at schools finished by secondary school-exit certificates (intended for further studies at universities) and non-graduation schools was roughly 40:60 before 1989; but as early as 1997 this ratio switched approximately $60: 40$ in favor of graduation secondary schools. The secondary apprentice training centres still attract a considerably high number of applicants (about $85 \%$ of all secondary school population). In 1995, it was resolved that the compulsory nine-year study, the last year of which could then be finished at the secondary school, must be fully passed at the primary school (except for the studies at multi-year grammar schools). The implication of this decision was a missing graduation year at all four-year secondary schools in 2000 . The number of students finishing grammar schools was about 12,000 in 1999/2000.

Education at secondary schools is organized either as day study or as extramural study (evening courses, correspondence courses, distance learning); the latter having the same curriculum but one more year than day study. Day study and extramural study are considered equivalent. The number of students interested in extramural studies dropped considerably after 1989; with the exception of extension courses, which then increased in popularity. However, about half of the students never complete their studies. Doubts relating to the quality of these courses led the Czech Ministry of Education, Youth and Sports in 1999 to limit the number of accepted applicants. Education is carried out in coeducational classes; apart from physical education. The Ministry of Education is in charge of producing the fundamental pedagogical documents intended for state schools. However, the Ministry entrusts respective bodies with the drafting of these documents; it coordinates their work and approves final wording of such documents. Informal groups of teachers, teachers' organizations and independent expertise associations contribute to the updating of the current curriculum and to the formation of new curricula. The documents that are prepared primarily by research pedagogical institutions are discussed with representatives of commissions which include specialists from universities, research institutes and schools, or representatives from the specific area of practice.

\subsection{Higher education}

Higher education is provided by both university and non-university institutions. The non-university higher education institutions mainly offer Bachelor study programs. Higher education institutions of university type offer Bachelor, Master and Doctoral study programs. Higher education institutions offer courses in the Humanities, Social Sciences, Natural Sciences, Engineering, Medicine, and Pharmacy, Theology, as well as in Economics, Veterinary Medicine, and Agriculture, Teacher Training and the Arts. 
The majority of institutions of higher education are public institutions. There are also 14 private institutions. Public institutions are financed by the state budget of the Ministry of Education. The private institutions of higher education can be partially financed by the State. In addition, the Czech system of higher education includes four state-based institutions of higher education. There are three military institutions of higher education and a Police Academy. These institutions are financed by the Ministry of Defence and the Ministry of Justice. All institutions of higher education provide accredited study programs which are assessed by the Accreditation Commission. Important partners of the Ministry of Education in all decisions concerning higher education are the Czech Rectors' Conference and the Council of Higher Education Institutions.

\section{University level studies}

University level first stage: Bachelor studies (Bc. = bakalar)

Universities, the highest level within the educational system, are granted full autonomy by law. Students are admitted on the basis of an entrance examination and their high school results.

The Bachelor study programs usually take three to four years, covering all the main disciplines except Medicine, Veterinary Medicine, Pharmaceutical studies, Architecture, and Law. The program is conceived either as an independent course of study whose graduates are fully qualified for particular professions, or as the first stage of longer studies whose graduates can continue towards the Master's degree. This cycle leads to the academic degree of Bachelor (Bc.), or Bachelor of Arts (BcA.) in the field of Arts which was introduced in January 1999. Students must sit for a final state examination, which includes the defence of a Bachelor's thesis.

\section{University level second stage: Master studies} (Mgr. = magistr)

The Master study programs in the Humanities, Education and Social Sciences, Natural Sciences, Pharmacy, Theology, Law and Art last five years and lead to the title of Master (Mgr.). In Economics, Agriculture and Chemistry, studies last five years and lead to the academic degree of (Universitytrained) Engineer (Ing.). In Engineering, studies take five or five-and-a-half years and also lead to the degree of Engineer (Ing.). In Architecture, Veterinary Medicine and Medicine, studies take six years. Graduates in Medicine obtain the degree of Doctor of Medicine (MUDr., from Latin medicinae universae doctor $=$ doctor of the entire (universal) medicine), and graduates in Veterinary Medicine acquire the degree of Doctor of Veterinary Medicine (MVDr.).

According to the 1998 Education Act, graduates of Master programs in Architecture are awarded the title of Engineer Architect (Ing. arch.), and graduates in the Arts, the academic degree of Master of Arts (MgrA.). The new Act enables holders of the title of Master to sit for a State Viva Voce examinations in the same field and defend a doctoral thesis to acquire the academic degree of Doctor followed by the name of the field; Doctor of Law (JUDr., from Latin juris utriusque doctor $=$ doctor of either laws), Doctor of Philosophy (PhDr.), Doctor of Natural Sciences (RNDr., from Latin rerum naturalium doctor = doctor of natural objects), Doctor of Pharmacy (PharDr.), and Doctor of Theology (ThDr.).

\section{University level third stage: Doctoral studies (Dr.} $=$ doktor)

The third and highest level of higher education consists in studies for the Doctorate, which take place under the guidance of a tutor. The program is based on scholarly research and independent study. Holders of a Master's Degree may apply. Studies last for three years (four to five years if part-time) and lead to the academic degree of Doctor (Ph.D.) or, in the field of Theology, Doctor of Theology (Th.D.). Studies conclude with the State Doctorate examination and the defence of a dissertation.

\section{Foreign language learning}

\subsection{Education of foreign language teachers}

In order to be qualified for teaching at basic and secondary schools, teachers must complete university studies. Teachers of foreign languages receive initial training at Teacher Training Colleges or Colleges of Arts. All regular teacher-training programs are concurrent; students follow a language -based program in educational theory, psychology and foreign language methodology, and also do practice teaching.

With the changed political situation after 1989, there arose an increased demand for teachers of English and German. The Ministry of Education initiated a nation-wide project aimed at producing a large number of well-trained teachers of English. This program was designed in cooperation with German and British consultants from the Goethe Institut and The British Council. The graduates are qualified for teaching English and German at elementary schools and the lower levels of high school. The course work leads to a Bachelor's degree. According to the National Curriculum, learning a foreign language is compulsory from Grade 4 of elementary schools. However, the schools face a great shortage of qualified language 
teachers. Some Teacher Training Colleges have introduced newly-formed language courses for Primary teachers in an effort to mitigate this shortage.

\subsection{Professional development of teachers}

Official support for language teachers is provided by the Regional In-service Educational Centres, most of which have foreign language specialists. Considerable support comes from institutions funded by the governments of Great Britain, the United States, Germany, Austria, France, Belgium, and Switzerland through their resource centres, which provide library facilities, hold seminar sessions and workshops, and, together with the Ministry of Education, select teachers for courses and exchange visits to the target-language countries. These activities form a closely interlinked network supported also by modern languages departments at various universities. Teachers of English, German, French, and Spanish have their respective professional associations, each of which holds an annual national conference, publishes newsletters, conducts regular specialist seminars, and contributes to in-service teacher training. Apart from that, there are a variety of courses across the country providing unqualified teachers of foreign languages with language training and modern language teaching methodology.

However, some teachers do not attend these seminars because they are resistant to speaking English in front of an adult audience. Before the coup of 1989, many Czech Western language teachers had to learn solely from textbooks; they had minimum contact with native speakers and they feel that their aural and oral skills are weak. The grammar-translation method prevailed in Czech schools in recent times, and, in addition, students strove to make no mistakes and therefore have a fear of speaking. These teachers often teach only vocabulary and grammar; they use mainly the mother tongue in class, and textbooks and workbooks with an emphasis on exercises are their safety belts.

At the same time, not every newly graduated teacher from the Teacher Training Colleges holds enthusiasm for a teaching career. Well-qualified teachers often look for better-paid employment in the private sector, such as sales representatives for business or medical companies. Relatively low salaries in our educational system present a significant problem for young people, who are often not able to make a living for their families. This situation has recently even been a theme of several popular sitcoms on TV. As a result, there is a chronic lack of foreign language teachers.
Many foreign language teachers, those who are already qualified as well as those in retraining, have numerous opportunities for educational visits to target-language countries. They can enroll in various European Community programs under Socrates, such as Erasmus, Comenius, Lingua, etc. There are also opportunities for teachers' initiatives and publications. The Association of Teachers of English publishes a newsletter, which provides information on foreign language teaching, conferences, courses, etc. it publishes contributions from both Czech and foreign language teachers. There are also other periodicals such as Perspectives, published by the British Council in Prague, and English Teaching Forum, published quarterly by the United States Department of State for teachers of English and distributed abroad by embassies of the United States, etc.

\subsection{Policy on language curricula and education}

After 1989, fundamental changes in the study of foreign languages occurred in institutionalized education. The politically and ideologically motivated position of Russian language study in basic and secondary education ended and was replaced by the language policy of the Council of Europe, of which the Czech Republic became a member in 1990. Students have the right and opportunity to choose one of five foreign languages at elementary schools (English, French, German, Russian and Spanish) and from six offered at secondary schools (also Italian). This choice is limited only by the staffing of the given school.

Although the students have the right to choose, the overwhelming majority of students chose between German or English. As our country borders Germany and Austria, parents and children tended to choose German over English as recently as only a few years ago; however, at this point English has become the dominant language.

According to the 1995 Amendment to the Educational Act, in effect since 1997, the first foreign language is introduced as an required subject from grade 4 of elementary school (students aged 9); by that time, students are supposed to be have mastered Czech sufficiently. Some schools offer a foreign language in $3^{\text {rd }}$ grade or even $1^{\text {st }}$. Beginners often start with an audio-oral program. They listen to tapes, and memorize chants and short conversation on everyday topics. They draw and color pictures with family members or school and home objects, and sing songs. After these initial stages a textbook is used.

The National Curriculum prescribes three 45minute language lessons per week, it also prescribes the structure and content of language 
teaching. The curriculum documents for modern languages deal with common aspects of the teaching of modern languages, and prescribe standards of achievement for listening, speaking, reading and writing. This includes lists of topics and communicative functions, and outlines the principles of communicative teaching methodology, including the development of students' language awareness and cross-cultural competence.

Students also have the opportunity to attend optional language courses after their regular classes. This type of language education is usually provided by private language agencies, which charge a fee for their services.

\subsection{Examinations}

All through their primary and secondary education, students receive school reports with grades for each subject twice a year.

At the end of their secondary education, students take a exit/graduation examination (usually at the age of 18). The foreign language examination is compulsory (with the exception of certain specialized schools, where it is possible to choose between a foreign language and mathematics).

In the State Language Schools, those interested in obtaining a certificate of their language competence can take various levels of the state language examinations, namely the Basic State Examination, the General State Examination, and the Special State Examination with a focus on written translation or on interpreting. According to the British Council, several thousand candidates in the Czech Republic have taken the Cambridge Examinations, with a success rate over $80 \%$.

\section{Conclusions}

In 1990, the Czech Republic became a member of the Council of Europe, and since this time it has participated in various projects promoting intercultural understanding among European citizens. It has also contributed to educational and occupational mobility in the new Europe.

The Czech Republic has made good progress over the past years in overhauling its system of education. Much work still needs to be done, however, especially in the area of foreign languages. The extension of foreign language education to the primary level will require extensive and intensive training of the teachers, both in pre-service and inservice courses. Furthermore, there is a pressing need for reforms to improve and guarantee the prestige of teachers in the Czech society.

\section{References}

[1] An Early Start: Young Learners and Modern Languages in Europe and Beyond. Compiled and edited by M. Nikolov and H. Curtain, European Centre for Modern Languages Council of Europe Publishing, 2000.

[2] Koucky, J.: Czech Education and Europe, Prague, Ucitelské noviny, 102, 1999.

[3] Malinovsky, M., Malinovska, E., Czech. An Audio Textbook. Pimsleur Language Program, Simon \& Schuster, New York, 2004.

[4] Malinovsky, M., Language, Learning, and the Education System in the Czech Republic. A lecture given at the University of New Orleans Prague Summer Seminars, 2005.

[5] Ministry of Education, CR. Concept of Education and Development of Educational System in the Czech Republic, Prague, Ucitelske noviny, 22, 1999.

[6] OECD. Reviews of National Policies for Education - Czech Republic, Paris, OECD Publications, 1996.

[7] Perclova, R., A Language Portfolio in the Czech Republic, Prague, Ministry of Education of the Czech Republic, 1999.

\section{The University of New Orleans presents "THE PRAGUE SUMMER SEMINARS" July 8 - August 4, 2007}

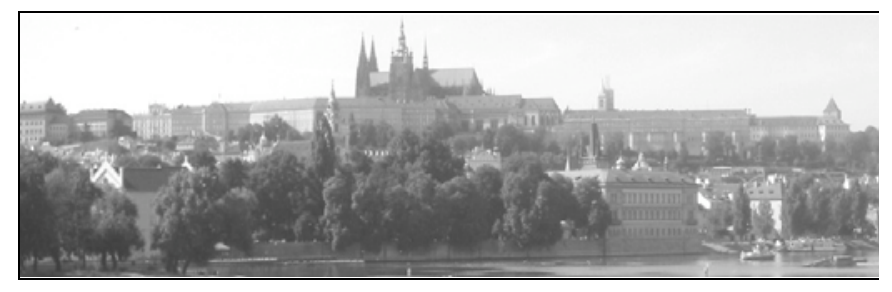

"The Prague Summer Seminars" is an educational program for students and adults, offered by the University of New Orleans. Entering its $13^{\text {th }}$ year in 2007, this program offers courses in Czech Language \& Culture, Music, Art, Architecture, Photography, Political Science, Business, Environmental Studies, and Engineering. Students earn six college credits, which are transferable to home institutions; post-graduate participants can enroll as non-degree seeking students. Extra-curricular activities include excursions in and around Prague, weekly lectures, walking tours, informal dinners, and weekend field trips to Vienna, Austria and Brno, Southern Moravia.

Prague Summer Seminars iziegler@uno.edu

University of New Orleans

Metropolitan College, ED 118

New Orleans LA 70148

http://inst.uno.edu/prague 


\section{Website announcement}

\section{http://www.slavistik-portal.de/en.htmI}

The Berlin State Library houses a virtual library ("Slavistics-Portal"), a central point of access for subject information for Slavistics via the Internet. The portal is directed to scholars and students, teachers, translators, journalists, and others who are interested in Slavistics in general, or the individual Slavic languages, literatures and folklores.

The Slavistics-Portal offers the following modules:

- The "Subject Gateway Slavistics" provides a database of online resources relating to Slavistics,

- The "Metasearch functionality" enables users to search multiple library catalogues simultaneously,

- The Online-Tutorial gives instruction (in German) on various topics relating to information searches in the field of Slavistics,

- The "Alerting Service Slavistics" provides users with information on new acquisitions of the Berlin State Library.

For more information, please write to Vladimir Neumann, Coordinator, at vladimir.neumann@sbb.spk-berlin.de, in Czech, Russian, German or English.

\section{The Pedagogical Foundations of the Philosophy of Jan Patočka}

On the 100th anniversary of Patočka's birth and the 30th anniversary of his death

Radim Palouš, Professor Emeritus and Former President of Charles University

Aleš Prázný, Department of Civics and Philosophy, Charles University

Editors' introduction: In 2007 we celebrate the hundred-year anniversary of the birth of the Czech philosopher Jan Patočka, one of the founders and first spokesmen of Charter 77. In honor of this occasion, Professors Radim Palouš and Aleš Prázný have contributed an article on the pedagogical foundations of Patočka's philosophy. For more information on Patočka, see the biography, bibliography, and other links at http://www.ajp.cuni.czl. For more information on Charter 77, see http://www.charta2007.cz/
Summary: Patočka's philosophy questions the generally accepted pedagogical concepts of the formation of human beings. The ontological starting point of Patočka's pedagogy is the natural world, not the world sub specie of the objectifying science, but the world of our experience. Pedagogy as the theory of upbringing and education posits an explicit question: what is education? - how should it be organized? - and in that respect, philosophy immunizes pedagogy against a scientific approach. On the horizon of the history of thoughts, particularly inspired by Plato, Patočka develops his philosophy of education and upbringing. From such a perspective it becomes obvious that the educative concern in Platonism is primary, thus the pedagogical nature of philosophy as care for the soul.

Recently, the aim of education is too often subsumed under the viewpoint of measurable usefulness of social demand or economic criteria. Resulting criteria of education imply a particular understanding of upbringing: education is classified just as any other object of science. In connection with the anniversary of the Czech philosopher Jan Patočka, it is inspiring to recall some of Patočka's pedagogical and philosophical concepts.

Pedagogy is always in a certain vivid relationship to the world, always implicitly interprets it and attempts to understand it. Jan Patočka in his study Philosophy of Education (Filosofie výchovy, 1938-1939) demonstrated that education is not a process of "assembling“ adequate reactions to stimuli as naturalism would have it, ${ }^{1}$ nor can it be reduced, as idealism regarded it, to the co-operation of an educator and a trainee, as a mutual penetration of souls. Both naturalisms and idealisms are too general and do not stem from a concrete analysis of educational phenomena as they are exhibited in the natural world of humans. Education belongs to the natural human world and cannot be regarded sub specie of the objectifying science. ${ }^{2}$ However, even in such a way educational phenomena cannot be grasped in all detail.

\footnotetext{
${ }^{1}$ Jan Patočka, Péče o duši I (Praha 1996), 398, 419: "Naturalism regards man as an object. It means that man is a part of nature, is a thing among other things, that he can be assessed only through observation, examination, experiments, and thus education is nothing but the inducing of appropriate systems of habits required of the individual by the society."

${ }^{2}$ Ibid. 421.
} 
According to Patočka, pedagogy itself begins when upbringing and education become explicit problems, when the natural human formation is rejected or put into question. Although human beings are, unawares, brought up by their natural cohabitation in society, we speak about pedagogy when human educative formation and learning is questioned. The theory of education inquires how this formation should best be managed and to what aim. The aim concerned is not partial, as it is sometimes the case in special qualifications, rather it concerns the entire human being.

Patočka seeks the answer to the question of what education is as well as whether it is possible to ask in such a general way: "Is not education a particular reality above all? Education is after all a certain social process; we have schools, educational institutions, authorities, etc., all of this social specialized educational function; so why do we want to interfere in it with our philosophical constructions? "3 Is actually philosophy of education applicable in the educational business, in the politics of education? Is not a state's organizing of its educational system only in connection with its political "ideology" sufficient? If philosophy wants to have an educational impact, it has to take all of this into consideration. Patočka demonstrates that it was Plato who elaborated the first extensive educational system in his Republic. He was particularly concerned with the relationship of a "just state": ${ }^{4}$ theories of upbringing and education must respect community, human polis.

Patočka asks how, in fact, an introduction to philosophy of education should be done, ${ }^{5}$ and he begins by turning toward the natural human world: neither philosophy nor education is an obvious subject that could be grasped "modo geometrico." "Philosophy is actually an attempt of self-thinking, the independence of the soul in intellectual terms. "6 The skills in philosophy are gained differently from other fields: there is no experimenting, calculating. What is then the use of this speculative knowledge for the real social process such as education?

Undoubtedly, philosophy is characterized by the aggrandizement from the prejudiced life stereotype to an insight into the true quality of reality. In this framework, philosophy divides its attention among the spheres of politics, history, morals, language, et cetera. The term "speculate" sometimes has a

\footnotetext{
${ }^{3}$ Ibid. 378.

${ }^{4}$ See also Hans-Georg Gadamer, Platos Staat der Erziehung (1942) in Gesammelte Werke 5 Griechische Philosophie I (Tübingen 1985).

${ }^{5}$ Patočka Péče o duši I, 363.

${ }^{6}$ Ibid. 363.
}

pejorative connotation: speculation is regarded as fantasy, which is in opposition to positive science. Positivism reduces philosophy by regarding it as a certain immature branch of science, as a theory that investigates questions that are not yet answerable by science. However, philosophy is not a simple introduction or prerequisite to positivism. ${ }^{7}$ What does this mean for education? Positivism claims that philosophy cannot contribute anything to education because it holds no exact findings that would be out of the reach of specialized science. Nevertheless, an activity exists that is of a different order: "In such an activity, in the inner movement, something new opens up within a man, such an activity transforms inwards."

The typical positivism of the 19th century accentuated classification of human knowledge within philosophy as well as outside of it. Some of these "specializations" later grew emancipated from their original ties with philosophy and were established as independent branches; logic and psychology can serve as an example. The former belongs, to a large degree, to the sphere of mathematics; the latter - especially the empirical and clinically oriented - exists as an independent science, although more theoretically oriented psychologists cannot deny the discipline's umbilical cord to philosophical reflection. Pedagogy has been considered an independent discipline in Europe since the 19th century, and more as a tradition founded by Comenius than a discipline separated from philosophy.

Comenius was, in his century, appreciated especially as a methodologist of languages (in Bayle's dictionary from 1695, Comenius is described as a "grammarian" in reference to his book Janua linguarum reserata); it was the philosopher J. G. Herder (1744-1803) who pointed out Comenius' universally pedagogical focus. Since then, pedagogy has established itself and assumed its recent shape, which is closely connected with Comenius' successful pragmatic "ars docend." Not until the 20th century, and thanks to the works of Patočka and Schaller, Comeniology, together with the philosophy of education, have again taken up their philosophical roots. Comenius himself wrote: "Thus no one should be a non-philosopher because we were created as rational beings and were

\footnotetext{
7 Edumund Husserl in Krizi evropských věd a transcendentální fenomenologie (Praha 1996) stated that "positivism, so to say, cuts the head of philosophy off," 31.

${ }^{8}$ Patočka, Péče o duši I 366.
} 
ordered to contemplate essences of things and to show them to others."

It must be stressed: the philosophy of education is not a philosophy applied to upbringing and education, but rather it lies at the core of philosophy itself. Ballauff's seminal book ${ }^{10}$ on the philosophical foundation of pedagogy is not written as an application of philosophy to pedagogy; however, the title itself does not rule such an interpretation out. Would not the title of Ballauff's work be more adequate if it were called "Pädagogische Begründungen der Philosophie," pedagogical foundations of philosophy?

School should not only lead pupils to gaining special skills and learning some information, but it should also teach them "to desire something new and higher."11 This "new" often comes when the security and certainty of one's natural surroundings that does not require a deeper reflection is destabilized, shaken, put into question. This break through "the dull normality" is for Patočka the starting point for education per se that gives meaning to European history. Suddenly, education is seen in a context that is usually not apparent: as a willful questioning of everydayness, which is unaware of the meaning of human life. A truly educated person has a different life orientation, has a historical consciousness, is capable of deep contemplation, and all this is important for the practical life as well.

From a historical perspective, this movement is, according to Patočka, most deeply present in the ancient times at the beginnings of Greek philosophy: "Philosophizing is a movement, a certain process inside of a human, and it is fundamentally connected with the leap away from a naturally naive and limited everydayness." ${ }^{12}$ Patočka sees education as such especially in the existential tremor apparent in Plato's dialogues. Often, this tremor starts with a feeling of shame: "Shame is a first signal that there is something else in the human, something he almost feels ashamed of, something genuine. Face to face with this genuine something, the false must give way, leave; a unique shock happens."13 The Greeks called this shock astonishment; in it a man is

\footnotetext{
9 J. A. Komenský: Obecná porada o nápravě věcí lidských. III. vol., Pampaedia (Praha 1992), 23: "Nemo igitur hominum non Philosophus esse debet: quia animal rationale factus, rationes rerum contemplari, aliisque commonstrare jussus."

10 Ballauff Th.: Philophische Begründungen der Pedagogik (Berlin 1966).

${ }^{11}$ Patočka, Péče o duši I (Praha 1996), 367.

${ }^{12}$ Ibid.

${ }^{13}$ Ibid. 368.
}

captivated by an interest in ideas: "An idea is not a particular piece of knowledge, no definite truth is discovered in an idea; to love an idea does not mean to understand the Pythagorean theorem, the laws of free fall or of any other natural processes. On the other hand it means to uncover certain complex aspect of things, to find the key that opens everything that exists and with this possibility to interpret all that exists, to open every entity and inquire about its meaning; that is the true core of philosophy." 14

Thus an educated person is in all his responsibility placed into the demanding and uncomfortable role of a pilgrim who can, however, serve to shield him from something given and undoubtedly mystic, even if safely offered. Patočka reminds us of the depth of the great narratives about the tragic aspects of human existence (such as Gilgamesh or Oedipus: man is a being expelled from the paradise of unawareness by his realization of his own mortality and his discovery of good and evil and is thus forever marked by this realization, this fundamental and un-atonable sin due to which he "always stands on the border between mere existing and living in the light.."15) However, man is, until the era of Greek philosophy, safely grounded in the consolatory position of spirituality and religion. In that respect, ancient Greek upbringing and education were far removed from the post-ancient European educational style. Prius means introducing/leading/entering into the realm of godsovereign and all that implies it, even if the seemingly secular (such as calculus, languages, astronomy, etc.) is subordinated to the already existing spiritual and state structure. ${ }^{16}$ Nevertheless,

\footnotetext{
${ }^{14}$ Ibid.

${ }^{15}$ Jan Patočka, Péče o duši II (Praha, 1996), 103.

${ }^{16}$ One illustrative example out of many: Babylonie see Hrozný B.: Vstup Přední Asie do dějin: Sumer, Akkad a Hethité in Dějiny lidstva, vol. Světla Východu a Hellady (Praha 1940): "Babylonian temples were, at the same time, Babylonian schools and universities, not unlike medieval monasteries. There Babylonian youth learnt the cuneiform writings and the Sumerian language, afterwards fallen into oblivion, as well as correct usage of the native Babylonian speech; there also mathematics, geometry, literature, even medicine and law were taught. Then of course theology itself - the youth got to know the innumerable Babylonian gods, ways to make sacrifices, the rules of the rites, etc. Different ways of reading the future were taught, such as astrology, but also incantations and evil spirits charming and illness spelling," (335-336). "Despite the relatively high level of the Sumerian-
} 
since the times of Socrates, PAIDEIA has meant bringing out, e-ducation, pulling out, Er-ziehung from the closeness of an established structure into a free, open space pregnant with potential. Human "freedom pregnant with possibilities" is a movement of the inside as well as of the outside between "here and there," a kind of "schizophrenia" of the soul of the human being "amazed by the secrets, by the eloquent silence at the fundament of life" who plays with himself "the discovery game, the magnificent chess game, the dialogue."17 Thus the person is open to this "game" (see Patočka's concept of the "open soul"). He accepts the risk of loosing the game: he has to be an eager player, a team player in a game where the "enemy" is powerful and mysterious. To open up the closed ones is the main mission of education, the "philosophy of education." Patočka stresses: "The task for the PSYCHÉ is PAIDEIA which consists of, firstly, a preparation for the upward turn already while in a low sphere, secondly of a strategy and a tactics of the turn itself, and of the attachment of the PSYCHÉ to the higher sphere."18

The education progressing from one soul to another always presupposes existence of the often mysteriously festive fellowship among teacher and pupils. Such education assumes that the truly great educational movements are never institutional. On the contrary, they are analogous to the relationship between religious prophets and their apostles, their loving disciples. This kind of relationship is constantly under threat of becoming a mere formality. A long exercise in discipline, "enormous constant control" should prevent the educational community from turning superficial. "Not any authoritative, direct, rationalistic institutionalism but the one based on gentle understanding of human motivation leading to a turn towards what are genuinely fundamental results of life" ${ }^{19}$ So education aims at saving the community of those who opt for the "theoretical life." The theoretical life is not a pale intellectualism, not a separation from one's body, but a turning away from mere instinctive existence. Theoretical life is the manifestation of a new value

Babylonian ethic opinions there is a fundamental difference between the Babylonian ethic and the ethic of the Old Testament. While Yahveh, the God of the Israelites, is above all the God of justice and moral order, the Babylonian gods are first of all personifications of various natural phenomena and only then somehow gods of justice and order" (ibid. 33).

\footnotetext{
${ }^{17}$ Patočka Péče o duši II, 104.

${ }^{18}$ Ibid. 70.

${ }^{19}$ Patočka Péče o duši I, 382.
}

system and life imperatives that lead the soul to the need of truthfulness.

Philosopher's ideas, nevertheless, often uneasily gain respect from society. Freedom is needed to enable ideas to get some feedback without which any talk is futile. Patočka sees a great danger in a situation in which there is nothing behind the utterance but the words and empty intellectual talent that does not refer to "real life." In school, the danger of mere verbalism is strong: values are passed down through tradition while their content is to no longer shared, "so finally, mere pulp is accessible to everyone, completely drained 'nothing' is left." ${ }^{20}$ Leveling and skepticism brought about by such empty education are only natural responses to the "molten maze of words," to that which is not in touch with real, natural life. Apparently, education has to move against institutionalization because institutionalization tends to level and because of its "spiritual dryness" is incapable of "making the human heart vibrate."

Naturally, one can point out Socrates' famous cave myth depicting a prisoner who is taken out of darkness into broad light and when he returns back he is "inflicted" by the challenge and the resulting spiritual unrest. The entire classical Greek philosophy was not an interesting collection of information and knowledge nor a part of educational curricula, but a truly "educational movement."21 This is the core of Patočka's ethos of educational philosophy of the open soul. The open soul is "an unmatched human misery and, at the same time, the only fortune a person has."22 The fortune and the misery is the gradation of insight, escalation of "concept/embracement," a pilgrimage forward enabling us to exceed our limits and the universe in terms of time and space. The "god-like" quality is for the "god-unlike" man burdensome and bewildering. Since he does not posses absolute sovereignty, he is but a limping pilgrim; the conclusion and the meaning of the toil slip through his fingers and shipwrecks in his individual aptitude.

An educated person, or more precisely, a "philosophically" educated person, is responsible and concerned. The responsibility requires him to render an account of his deeds and thoughts and strives for his own as well as communal goals: genuine philosophy awakens responsibility. Patočka considers education as bearing witness to the formation of an autonomous objective, which the

\footnotetext{
${ }^{20}$ Ibid. 380.

21 "Example: Greek philosophy was a great educational movement. It was no academic philosophy, it was a true movement" (ibid 381). ${ }^{22}$ Patočka Péče o duši II, 44.
} 
trainee attempts to fulfill: the teacher then encourages him on the journey through which the trainee gradually assumes the role of the teacher. Self-education is the acceptance of the teacher's will for the deepening of oneself. However, the drive for the fundamentally important is not the same as benefits stemming from practical, professional knowledge where knowledge and the knowing remain separate. In our case, on the contrary, life acquires itself. The advantage of philosophy differs greatly from the benefits of undoubtedly useful special branches of science because the advantage of philosophy concerns human and universal reality in its totality: "Philosophy is the ability to think, to capture what dominates the wholeness of life, what gives it a meaning. Pedagogy as a theory of education, on the other hand, always presupposes a particular idea of the meaning of life.,"23 "Learning is but a free adoption of aims that are socially acceptable and already exist in the culture, aims which give meaning to life. The emblem of true learning is the cooperative formation of these aims and objectives." ${ }^{24}$ Quite simply, what is important is that which is universally humanly valid as alive ideas, the "ideal." Patočka sees this threatened not by a "lack of education or learning" but by a false idea of what should constitute genuine learning. This illusory education characteristically gathers knowledge without bringing joy into life. In fact, it is the entrapment by material that prevents one from fine thinking in nuances: it spreads clichés, conventions, uncultured life.

The adjective „alive” is crucial here. The human soul is indefinite, although it exists inside each human being. It is, however, as mobile as any other creature in the universe! $!^{25}$ The human soul is always a concern, it does not face oneself as the other but is at any time its own engagement. ${ }^{26}$ "Learning is truly alive; education cannot be conceived as training and drill during which we can do whatever we want with a particular material. This is life, and whenever it gets overly mechanized, whenever it is restricted to prescribed paths, it

\footnotetext{
${ }^{23}$ Patočka Péče o duši I, 372.

${ }^{24} \mathrm{Ibid} .418$.

25 "The soul is originally unaware of itself precisely because it is in motion, because it does not stand in front of itself as in front of a theater performance. Rather, it always faces itself in a way that pre-decides about itself. As a result, the soul has also decided about what it can see, uncover, understand from the things surrounding it as well as about itself" (Patočka Péče o duši II, 79)

${ }^{26}$ Ibid. 44.
}

always takes revenge even if only in the oft parodied form as the over-regulated method. And you know well that the profession of educators in particular is subject to far too many comic and laughable moments. “27

Patočka's philosophy of education is a pedagogical concern or care for the human soul, that is, for that which makes a human being a human being - a creature capable of transcending the situational, individual as well as social, immersion.

\section{SVU Student awards: Dr. Joseph Hasek award}

The main purpose of the Society's awards is to generate and encourage scholarly interest in Czech and Slovak affairs among university students living outside the Czech and Slovak republics. There will be one prize for the best undergraduate and one for the best graduate study dealing with some aspect of Czech and/or Slovak history, politics, or culture. The winners will receive the $\$ 250 \mathrm{Dr}$. Joseph Hasek award, a year's membership in the Society, which includes a year's subscription to the Society's newsletter, and a Certificate of Merit.

The following rules apply:

l) The paper must be submitted by the professor in whose class it was presented and should be accompanied by his recommendation. Submissions are only accepted from institutions outside the Czech Republic and Slovakia.

2) The study must have been written for an undergraduate or graduate course during the academic year 2006-2007. Chapters of theses or dissertations are not admissible.

3) The deadline for submission is MAY 15, 2008.

4) The study essay should be submitted in triplicate to Professor Vera Borkovec, 12013 Kemp Mill Road, Silver Spring, MD 20902. It must be typewritten, double-spaced and submitted in Czech, Slovak, English, French or German.

Submitted papers will not be returned.

5) The Student Awards Committee which will judge the quality of the submitted essays consists of: Prof. Ivo Feierabend (San Diego State University), Prof. Milan Hauner (University of Wisconsin), and Chair, Prof.

\footnotetext{
${ }^{27}$ Patočka Péče o duši I, 431.
} 
Vera Borkovec (American University).

The SVU is a nonprofit, nonpolitical, cultural organization, dedicated to the pursuit of knowledge, the free dissemination of ideas, and the fostering of contacts among people. It brings together scholars, scientists, artists, writers, students, lawyers, businessmen, and others throughout the world who have a professional, family or other interest in the Czech Republic and Slovakia, their history, peoples, or their cultural and intellectual contributions.

\section{Jan Balhar a kolektiv: Český jazykový atlas 5.}

Nakladatelství Academia, Praha 2005, 680 str. (ISBN 80-200-1339-3)

V roce 2006 (s vročením 2005) vyšel v České republice závěrečný svazek Českého jazykového atlasu (ČJA) ${ }^{28}$ Pátý, nejrozsáhlejší díl jazykovězeměpisné syntézy českých nářečí nemá tentokrát monotematický charakter jako díly předcházející. Věnuje se hláskosloví, syntaktickým jevům, adverbiím, zpracovává výsledky dodatečného výzkumu ve městech a $v$ závěrečné části přináší mapy izoglosových svazků, v nichž jsou zužitkovány poznatky ze všech pěti dílů atlasu.

Cílem několik desítek let trvající práce českých dialektologů (s konkrétní prípravou výzkumného programu se začalo na počátku 60 . let 20 . století) bylo podat obraz zeměpisného rozvrstvení běžně mluveného jazyka na území Čech, Moravy a části Slezska, a to $v$ rovině hláskoslovné, tvaroslovné, slovotvorné, lexikální a syntaktické. Na jednotlivých mapách i v komplexnosti celého díla je možno na základě konfrontace přinejmenším tří jazykových vrstev sledovat vývojový pohyb v mluvené češtině v průběhu sta let. Pozorovatelné jsou nivelizační procesy, teritoriálně i sociálně podmíněné interference tradičních nářečí $s$ interdialekty i $s$ útvary charakterizovanými víceméně celonárodním rozšírením a celospolečenskou prestiží (spisovným jazykem a obecnou češtinou).

Počáteční tři díly ČJA, které vyšly $v$ letech $1993{ }^{29} 1997,1999$, se zaměrily na zobrazení lexikálních a slovotvorných nářečních rozdílu $v$ češtině, čtvrtý díl zachytil tvarosloví, tj. sledoval územní diferenciaci gramatických forem ohebných slov.

\footnotetext{
${ }^{28}$ Recenze 4. dílu přinášející obecné informace o ČJA a charakteristiku prvních svazků vyšla v CzLN 20, 2003, s. 8-9.

${ }^{29}$ 1. díl ČJA se v r. 2004 dočkal reedice.
}

Pátý díl ČJA by svou tematickou heterogenností mohl navodit představu, že jde už jen o jakési shrnutí toho, co se nikam nehodilo, co prostě autorům „zbylo na stole“. Opak je však pravdou. Čtenářưm se představuje práce, která dưstojně završuje celé rozsáhlé dílo, přináší mnoho nového v materiálové i výkladové rovině a také $v$ oblasti metodologické dále rozvíji a obohacuje už dríve precizně vypracované postupy.

První a zároveň nejrozsáhlejší část pátého svazku ČJA (400 stran!) je věnována hláskosloví. Jde o systematicky uspořádaný popis zahrnující jak pravidelné hláskové obměny, zpracované už $\checkmark$ úvodu každého předchozího dílu $v$ rámci soupisu tzv. Pravidelných regionálních obměn, tak diference méně pravidelné či nepravidelné. Přestože této jazykové rovině věnovala diachronní jazykověda i sama dialektologie značnou pozornost už od devatenáctého století, výsledky detailního nářečního výzkumu zpřistupněné v ČJA výrazně obohacují dosavadní poznání. Asi nejvýznamněji se to projevuje voblasti zpracování kvantity, jehož komplexnost nemá $v$ české jazykovědě obdobu. Největší prostor je věnován registraci kvantitativních rozdílů v základech slov (nejčastěji substantiv), zvláštní čtenářskou pozornost si však zaslouží speciálně vyčleněný pododdíl zachycující nářeční kvantitativní diference provázející derivační procesy (např. územní rozdíly $v$ délce vokálů deminutiv schodek / schůdek, mostek / můstek). Tato problematika se netýká jen tradiční jazykovědy, ale zajímá dnes např. i lingvisty zkoumající češtinu $\checkmark$ rámci paradigmatu generativní fonologie (srov. studie Tobiase Sheera, Markéty Zikové ad.).

Rozsahem menší (zhruba 50 stran), významem však neméně závažná je část věnovaná teritoriálním diferencím $z$ roviny syntaktické. Jazykovězeměpisné práce syntaktické jevy vzhledem k obtížnému výzkumu a problematickému záznamu dosud opomíjely, v této oblasti Ize proto tvưrcům ČJA bez nadsázky priiřknout prvenství. Zachycení územně vázaných rozdílů ve větných konstrukcích se radí $\mathrm{k}$ tomu nejzajímavějšímu, co pátý díl ČJA přináší: např. šlo nás jich tam pět / šlo jsme jich tam pět / šli jsme jich tam pět; co je to za člověka / co je to za člověk; je mu Josef / je mu meno Josef / je mu na myno Josef; je mu šedesát let / je šedesát let / má šedesát let; šel $k$ pekaři / šel do pekaře. Okrajově se syntaktický oddíl zmiňuje také o územních diferencích $v$ přízvuku a melodii.

Tretí oddíl pátého svazku ČJA přináší důkladné a relativně komplexní zachycení adverbií, tj. méně nápadné, ale frekventované části slovní zásoby, která bývá $v$ dialektologických pracích většinou spíše upozad'ována. Mapy ČJA ukazují, že také v užívání adverbií se projevují poměrně jasně 
vymezené územní diference, ačkoli si je mluvčí právě u tohoto slovního druhu zpravidla málo uvědomuji a teritoriální príznakovost $v$ projevech jinonářečně zakotvených uživatelů češtiny někdy mylně interpretují např. jako př́znak vyššího či nižšího stylu, archaičnosti apod. (moc / tuze / velice; taky / také / též).

Do pátého díluČ JA byly dále ve výběru zařazeny některé výsledky doplňkového výzkumu $v$ městské síti (uskutečněného podle dotazníku o 139 položkách), který sledoval jednak pojmenování reálií a jevů typických pro město (např. 'tramvaj': tramvajka / elektrika / elinka / šalina), jednak některé výrazy mládežnického slangu (např. 'sestra': ségra / švica / švigra). Uvedení tohoto materiálu ukazuje pozoruhodnou skutečnost, že areálově vymezené diference se uplatňují také v pojmenováních novějších, převážně „městských“ reálií (srov. např. výrazné česko-moravské rozdíly napínáček / rýsováček; kostička čokolády / čtvereček čokolády), resp. i v žákovském slangu.

Zakončení pátého dílu ČJA a do jisté míry završení celého atlasu představuje velmi cenná část zachycující svazky izoglos nářečních jevů (všech jazykových rovin) excerpované z kompletního mapového souboru ČJA, tj. $z$ téměř 1600 map. Autorka této syntézy S. Kloferová v souboru 15 mapových listů představila 60 výrazných izoglosových seskupení vytvářených navrstvením vždy alespoň 10 hraničních linií. Mapové zobrazení je uvedeno poměrně rozsáhlou textovou částí, která obsahuje jednak vstupní pojednání o obecných otázkách územní stratifikace národního jazyka, jednak detailní deskripci izoglosových svazků, tzn. jejich územní vymezení, výčet relevantních nářečních jevů a přehled nejvýznamnějších jazykových i mimojazykových okolností, které mohly vytvoření svazků tak či onak ovlivnit. Tradiční teritoriální dělení českých dialektů (jehož kořeny najdeme už u A. V. Šembery, detailnější ustanovení pak zejména v syntéze B. Havránka Nářeči česká, 1934) vychází z diferencí v oblasti hláskoslovné. Za rozhodující kritérium vydělující čtyři základní nářeční skupiny češtiny byly zvoleny rozdíly v responzích za pưvodní ý, ú. Zásluhou ČJA se však ukázalo, že na území českého národního jazyka existují i četné jiné areály se žretelnými obrysy, o nichž dialektologové před výzkumem pro ČJA věděli poměrně málo, případně je neznali vůbec. Novum predstavují zejména poznatky o areálech vymezených svazky lexikálních izoglos.

Pátým svazkem ČJA se uzavírá dílo výjimečné rozsahem, obsahem i kvalitou zpracování. K jeho přednostem patří též rychlost a plynulost vydávání, která je u projektu takové šîre značně neobvyklým jevem. Zájemcům o češtinu se celý informačně neobyčejně bohatý komplex dostal do rukou během pouhých dvanácti let.

Poznámka: Český jazykový atlas pátým dílem končí, kolektiv Dialektologického oddělení ÚJČ AV ČR v Brně však připravuje ještě dodatkový svazek, který bude zahrnovat rejstříky a řadu doprovodných informací.

Zdeňka Hladká

Masarykova univerzita, Brno

Česká republika

\section{Zprávy bleskem}

Peter Zussi has landed a job at University College London where he will be teaching Czech and Slovak language and culture.

Jeff Holdeman of Indiana University will host an "Evening of Czech Music" at the AATSEEL annual meeting in Chicago-December 29th, $7 \mathrm{pm}$.

\section{Book Reviews}

\section{Craig Cravens. Culture and Customs of the Czech Republic and Slovakia. Westport, CT: Greenwood Press, 2006. 216 pages. $\$ 49.95$}

The preface of The Culture and Customs of the Czech Republic and Slovakia declares the author's intention "to go beyond the stereotypes and clichés" as he explores the cultural achievements and peculiarities of these neighbors and erstwhile confederates. This is a laudable goal for a popular study of a region that only twenty years ago was shrouded in mystery and whose public face is now increasingly drenched in touristy kitsch, and Cravens succeeds handily. Informative, engaging and written in an unadorned, readable style, this book serves layman and student alike, offering a broad introduction to the Czech and Slovak people peppered with odd trivia and suffused with dry wit.

This, the seventh title in the Greenwood Press "Culture and Customs of Europe" series, is an attractively packaged survey of the region's history, habits and culture, both highbrow and low. Its ten chapters are organized thematically, the book's first half an exposition of contemporary life in the two countries and the history that informs it (Chapters One and Two, for example, are titled "Land, People, 
and History" and "Thought and Religion," respectively), the second half a detailed catalogue of Czech and Slovak fine arts with special emphasis on the $20^{\text {th }}$ century. In the latter, Cravens helpfully integrates explications of more general European phenomena such as the Baroque and Cubism into the passages on specifically Czech manifestations of these movements. The chapters (each about 18 pages long) may be read in succession or discretely, as each one provides necessary background information for the subject at hand; a disadvantage of this method is a certain amount of repetition, which could be eliminated with more comprehensive cross-referencing. Each chapter concludes with footnotes and a useful Selected Bibliography which highlights a range of relevant scholarly, popular and artistic literature. Finally, the book contains several photographs and a handful of tables; the photographs are a welcome feature, while the inclusion of the tables, which measure such things as market share of the various television stations, is generally arbitrary and unhelpful.

Even the specialist has something to learn by reading Culture and Customs. How many Bohemists know that Czech mothers and fathers have the longest parental leave in the world; that a Czech language hotline exists, taking over 10,000 calls a year; that since the Velvet Divorce Slovak and Czech celebrants have assembled annually before the New Year at a border resort to ski, hike, make merry and generate mutual goodwill; and that Harlequin, which is the fourth largest publisher in the Czech Republic, releases its Czech-language novels in 28-day intervals to match the menstrual cycle? More than an agglomeration of facts and statistics, however, the guide usefully traces and explains the development of familiar circumstances and contemporary trends, such as the place of intellectuals in Czech and Slovak public life, the central role of the pub in the National Revival, the overwhelming prevalence of atheism in the Czech lands and the hostility to feminism in both countries after 1989.

While the book avowedly adheres to the model prescribed by the series to which it belongs, it also presents an idiosyncratic journey through a subject that the author clearly knows on a closely personal level. The section on cuisine (somewhat oddly coupled in Chapter Five with fashion), for example, which should not be read on an empty stomach, provides a wealth of useful information on beer, pubs and pub etiquette. Cravens, Fellow of Czech Studies at the University of Texas at Austin, similarly betrays his preoccupations and predilections in the arts and literature, devoting a page to the sibylline giant Jára Cimrman, two pages to the writer Karel Čapek and three to the avant-garde group Devětsil, while according the whole of Czech classical music a mere two pages. His readiness to turn his critic's eye on certain subjects is most conspicuous (and most caustic) in a long passage on the "far from unproblematic" Milan Kundera, whose compulsively proprietary relationship with his older works comes in for disapproval and whose "vocal authorial narrator" is said to "utterly overshadow the other characters, which function as mere ciphers for the author's philosophizing."

Cravens's style is charged with pointed understatement, yet occasionally veers in the opposite direction into mischievous hyperbole. Božena Němocová's supremely dull Babička is laconically labeled "uneventful," whereas the mullet is said to be "the standard haircut of all Czech and Slovak athletes." Noting that Czechs drink 163 liters of beer per person per year, Cravens helpfully observes the implications for Czech adult males, given that "women and infants tend to [...] prefer wine and milk, respectively." On a related subject, he considers the repercussions of the near doubling of the price of beer in 1984 from $1.70 \mathrm{Kč}$ to $2.50 \mathrm{Kč}$, an unpopular measure that presumably lowered consumption and thus led "ineluctably" to the Change five years later. His point about the revolutionary lethargy of a nation whose modern political culture was weaned on the frothy haze of the Prague krčma is well taken, and I suppose he might dare you to disprove it.

The book is somewhat marred by a number of typographical errors, particularly in the first few chapters. Two sins of omission deserve mention as well. First, no cultural survey is complete without a discussion of national mythology and, while Culture and Customs adequately addresses the long shadows cast by such historical figures and events as Hus, Žižka and White Mountain, no mention is made of the rich tradition of folktale and fantasy that informs so much of Czech and Slovak literature and music. Secondly, the book is predictably bedeviled by a problem that characterizes many works purporting to address both members of the former Czechoslovakia: a tendency to accord the Slovaks little more than a perfunctory nod. Cravens attentively avoids the pitfall throughout the book's first half only to fall victim in the fine arts chapters, devoting only a page of the ample Literature chapter to Slovak works, only a paragraph of the cinema section, and tacking a mere sentence onto the lengthy passage on rock'n'roll. 
These complaints are minor, however, and are eclipsed by the book's appeal as an erudite, lucid and broad overview of Czech and Slovak culture which engagingly explores terrain both familiar and strange.

Tim West

Princeton University

This book may be ordered online at http://www.greenwood.com/.

\section{SVU Conference Ružomberok, Slovakia, September 8-September 14, 2008}

The Czechoslovak Society of Arts and Sciences (Společnost pro vědy a umění) will hold its 24th World Congress from September 8-14, 2008 at the Catholic University in Ruzomberok, Slovakia. This congress has special significance as it will commemorate the 50th anniversary of the foundation of the Czechoslovak Society of Arts and Sciences, commonly referred to as SVU. The event will be multidisciplinary in nature and the working language will be English. Please consult the website www.svu2000.org for details concerning calls for papers, registration, accommodation, etc.

\section{Cimrman Corner}

The editor of this section is on temporary assignment at the North Pole where he is Investigating the Loss of the Class Book at a Pub in the Glade whence he will travel by Parlour Car to Africa Among the Cannibals where he hopes to locate the Czech Tarzan ... With real rain.

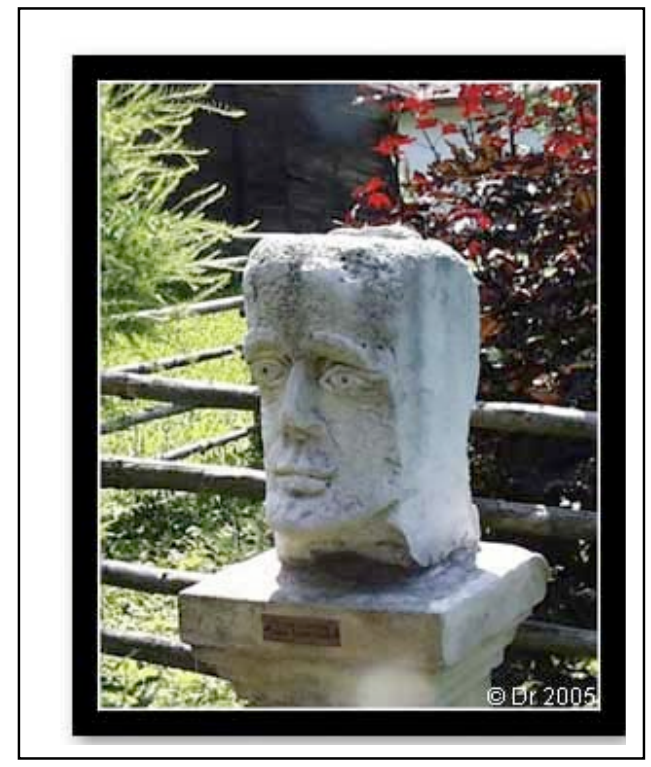

\section{Stone sculpture of Jára Cimrman} unearthed at Říp 


\section{Czech Events Network}

Czech Events Network (CEN) www.czechevents.net has been assisting the Czech community organizations in the US and Canada with decreasing of the cost of bringing in artists and groups from the Czech Republic, as well as offering overall information about the availability of Czech cultural events in the US and Canada.

There are many musicians, theatre and dance groups, art exhibitions and films which are coming across the Atlantic to the US and Canada. However, they usually perform or exhibit in New York, Chicago, Washington and Los Angeles, or in Toronto and Montreal, but they very seldom venture to other cities. In addition, there are extremely talented artists back in the Czech Republic (and Slovakia) who would love to perform in North America. The task of our service is to bring new artists, as well as to extend the North American stay of those artists who are already coming to the US and Canada, while saving on the cost of transatlantic flights by sharing the travel expenses among more organizers.

Since the spring of 2007, The CEN has been organizing an information and co-ordination service providing information about Czech artists' availability for the Czech communities, clubs and institutions in North America. It has been creating a database of artists, their agents and related cultural institutions in the Czech Republic, as well as an internet based matchmaking system. Please visit www.czechevents.net.

Apart from booking availabilities in 2008 and 2009, you will find lists of Artists, Orchestras \& Ensembles, Agencies, the calendar of Events 2007 across the US and Canada, scheduled events 2007/2008, Events in the Czech Republic related to North Americans, dozens of Czech TV channels on line, even more Czech radio stations on-line, links to Czech clubs and restaurants in the US and Canada, art galleries and visual artists, Czech theatres and other pertinent information.

To take advantage of this service, please fill out and submit the questionnaire at the following website http://ccrcc.net/CNACC/news.html

\section{Asociace učitelů češtiny jako cizího jazyka (AUČCJ) Program for the year 2007}

April 14: Sociokulturní aspekty při výuce německy mluvících studentů II June 9: Autorská práva, citace, Valná hromada (volba nového výboru AUČCJ)

October 6: Obecná čeština ve výuce češtiny jako cizího jazyka

December 1: Využití filmu, internetu a autentických materiálů při výuce češtiny jako cizího jazyka

Kognitivni; lingvistika, metafora v cizím jazyce

For more information, please see the AUČCJ website, available at http://www.auccj.cz/menu.htm 


\title{
CALL FOR PAPERS
}

\author{
9TH ANNUAL CZECH WORKSHOP \\ APRIL 25-27, 2008
}

\author{
NORTHWESTERN UNIVERSITY \\ EVANSTON AND CHICAGO, IL
}

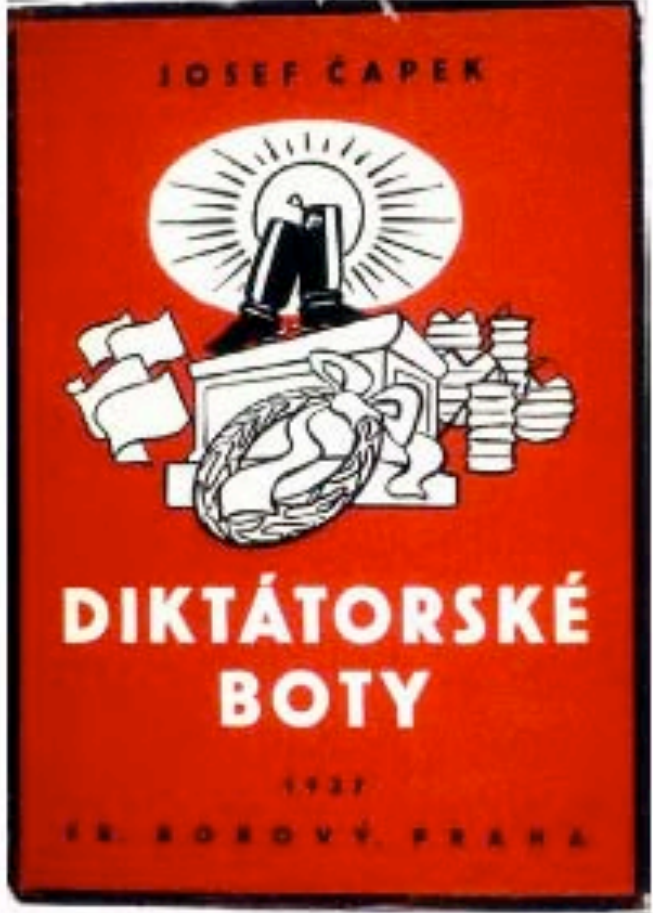

(5) Smithsonian Institution Libraries

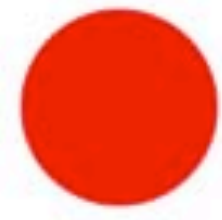

The Ninth Annual Czech Workshop welcomes papers on Czech, Bohemian, Moravian, and Czechoslovak topics, broadly defined, in all disciplines. In the past our interdisciplinary conference has drawn participants from colleges and universities in the United States and abroad. Areas of interest have included anthropology, architecture, art, economics, film, history, language methodology, literature, music, philosophy, politics, religion, sociology and theater. Work in progress is appropriate for our workshop format. Junior faculty and advanced graduate students are particularly encouraged to participate. We also invite suggestions for roundtables.

Please send your abstract of approximately 250 words to:

Czech Workshop at Northwestern University

Roberta Buffett Center for International and Comparative Studies

1902 Sheridan Road, Evanston, IL 60208-4005

We encourage submission via e-mail: r-koryan@northwestern.edu

Please include your name, full address, institutional affiliation, daytime telephone, fax, and email address with the proposal.

For more information contact Prof. Benjamin Frommer,

Department of History, Northwestern University

b-frommer@northwestern.edu

Deadline for submissions is Friday, December 7, 2007.

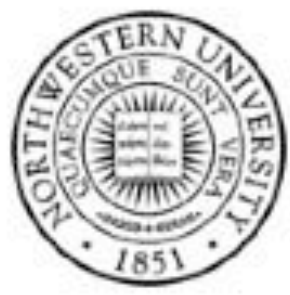




\section{All members: Please mail the form below to:}

IATC-NAATC

Department of Slavic and Eurasian Studies

University of Texas at Austin

Calhoun 415

Austin, Texas 78713

or fax it to 1-512-471-3607 attention Craig Cravens.

2008 Membership Dues: $\quad$ Regular Members: $\quad \$ 20$

Student Members: $\quad \$ 8$

Institutional Members:* \$75

* Institutional membership dues include one free advertisement (half page), a mailing list of IATC-NAATC, and five copies of the Czech Language news.

Payments to IATC-NAATC should be made by means of personal checks or money orders payable to the University of Texas at Austin.

Members in the Czech Republic and other countries outside North America: Please contact Craig Cravens at svejk@mail.utexas.edu for their method of payment.

2007 IATC-NAATC Membership Application Form

NAME:

Institutional Affiliation:

Address:

Telephone (optional): home:

work:

Fax:

Email address:

Please enclose a check or money order payable to the University of Texas at Austin 